same extended influence as in that of Crustacea. Mollusks, if we except oceanic species, are no travellers, and keep mostly to narrow limits.

XIII. There is evidence, in the exceedingly small number of torrid-zone species identical in the Atlantic and Indian Oceans, that there has been no water-communication across from one to the other in the torrid zone, during the period since existing species of Crustacea were first on the globe.

XIV. As to zoological centres of diffusion for groups of species, we can point out none. Each species of Crustacea may have had its place of origin and single centre of diffusion in many and perhaps the majority of cases. But we have no reason to say that certain regions were without life, and were peopled by migration from specific centres specially selected for this end. If such centres had an existence, there is at present no means by which they may be ascertained. The particular temperature region in which a species originated may be ascertained by observing which is most favourable to its development: we should thus conclude that the Ranina dentata, for example, was created in the subtorrid region, and not the torrid, as it attains its largest size in the latter. By pursuing this course with reference to each species, we may find some that are especially fitted for almost every different locality. Hence we might show, as far as reason and observation can do it, that all regions have had their own special creations.

The world, throughout all its epochs in past history, has been furnished with life in accordance with the times and seasons, each species being adapted to its age, its place, and its fellow species of life.

VI.-On Anthracosia, a Fossil Genus of the Family Unionidæ. By William King, Professor of Mineralogy and Geology in Queen's College, Galway, Corresponding Member of the Natural History and Medical Society of Dresden, \&c.

[With a Plate.]

Tнe lakes, rivers and estuaries of the Carboniferous period were inhabited by two groups of Bivalves; the generic characters of neither have as yet been fully described. One group includes forms having much of the external aspect of ordinary species of Unio; while the other comprises members possessing the outward appearance of certain aviculoid forms of Modiola.

But as external resemblances are not always to be depended on in determining the genus of a fossil shell, some palæontologists have gone no further, in the present case, than merely to refer the bivalves in question to the genera named; while 
others have placed the Unioniform shells in the totally distinct genus Cardinia, and the Modioliform species in that of Myalina.

As it is possible that I may have to notice the last-named genus on a future occasion, I purpose confining myself, in the present paper, to the Unioniform group.

Some years back, when residing in Newcastle-on-Tyne, I occasionally obtained some good casts and testiferous specimens of the so-called fossil Unios from Jarrow pit and some others in that district; also from a clay-ironstone band near Whitley.

On examining these specimens, I ascertained that they possessed certain characters sufficiently distinctive, and were deficient in a very important one, to warrant their removal from the genus in which they were usually placed. This led me to propose, in the Annals for November 1844*, a new genus for the fossils in question, under the name Anthracosia, on the occasion of my nominating and describing some other fossil genera,-intending to publish the diagnosis of it shortly afterwards. I need not enter into any explanation of the causes which have prevented this intention being carried out; suffice it to say, that, as several parties have adopted the name I proposed, and as no one, that I am aware of, has yet published any generic description of these fossils, I feel myself bound to take up the subject, even after the lapse of so many years.

The character which Anthracosia is deficient in, exists in all the known genera of Unionida. It consists of a largish scar in each valve, situated immediately behind the impression of the anterior adductor muscle, and which is evidently supplementary to the usual number of retractor muscles belonging to the foot of other Dimyarian shells, and inserted within or near their umbonal cavities. To distinguish the scars left by the supplementary muscles from those produced by the ordinary anterior foot-retractors, they have sometimes been termed "supplementary pedal muscular scars."

Reverting to the Unioniform fossils, several fine casts have passed under my notice; but in none have I observed the "supplementary scars,"-only those usually situated, as in ordinary bivalves, within or near the umbonal cavities. The remarkably fine cast, represented in Pl. IV. fig. 5, is exceedingly instructive in this respect.

The absence of these scars appears to have given rise to the opinion, that the fossils under consideration, though admitted to be freshwater species, belong to a marine genus, or, at least, to one (Cardinia) originally formed for some well-characterized marine shells.

* "On a new Genus of Palæozoic Shells."-Annals and Magazine of Natural History, vol. xiv. 1844. 
But, notwithstanding the absence in Anthracosia of the supplementary scars peculiar to the Unionida, there can be little doubt, from the presence of another essential feature, of the genus belonging to the family just named.

In most Dimyarians, the ligament extends from the corselet (where it covers the cartilage, when this last part is external) to a little in front of the umbones; but the umbonal portion is seldom well developed, except in certain species-notably in $\mathrm{Cy}$ prina Islandica, in each valve of which it occupies a rounded cavity, excavated in the hinge-plate immediately beneath the umbone, and in front of the cartilage. In the Unionida, however, the umbonal portion is as much developed as the corselet division; and that part of the hinge-plate, on which it is situated, is never separated from the teeth by so marked a line of demarcation as prevails in marine shells. These peculiarities may be distinctly observed in our British Unios: they are also to be seen in Unio littoralis, and more or less in all the American species. In these, as well as marine shells, the corselet ligament is more compact than the umbonal portion,- the latter being composed of imperfectly conjoined laminæ, which, in Unionida, produce a number of parallel curving linear impressions, commencing from above the cardinal teeth, and descending behind them, nearly to the inner or free margin of the hinge-plate. When the umbonal portion of the ligament is removed, impressions of its constituent laminæ are quite obvious on the hinge-plate.

The fossil genus Anthracosia has evidently possessed the ligamental peculiarities of the Unionida in an eminent degree, as that part of the hinge-plate on which the umbonal ligament was implanted is comparatively large and deeply excavated;-indeed, in the typical species it is much larger and deeper than in any existing forms that have passed under my notice.

I repeat then, there can be little doubt that its ligamental characters prove the genus Anthracosia to be a member of the family Unionida; but as its mollusk was not furnished with the usual supplementary pedal muscles, it may be considered as representing an abnormal section.

\section{Family Unionide.}

\section{Genus Anthracosia*, nobis.}

Sxn. Unio, Sowerby and others.

Pachyodon, Brown (not Stutchbury).

Cardinia (in part), Morris and others.

Diagnosis.-Equivalved: inequilateral. Teeth-one in each

* From $\stackrel{\prime}{\nu} \theta \rho a \xi=$ carbon, in allusion to the carbonaceous deposits in which the genus is usually found. 
valve below the umbone, rather low and massive : crown of tooth of right valve excavated anteriorly and ridged posteriorly: crown of tooth of left valve ridged anteriorly and sloped posteriorly. Umbonal ligamental fulcra, each a furrow excavated in the hinge-plate, between the umbone and tooth. Scars of the anterior set of pedal muscles situated above the anterior adductor muscular impressions.

Typical species, Unio Beaniana*.

The dental system of Anthracosia is much simpler than that of most Unionida; and it differs so much from what usually prevails in the family as to appear formed on a totally different plan. The dental formula is merely-Cardinals $\frac{1}{1}$; and the interlocking of the teeth is simply thus - the excavation of the right-valved tooth receives the ridge of the left-valved one; and the ridge of the former fits on to the slope of the latter, as is exhibited in the diagram section represented under fig. 3, Pl. IV. In other dentiferous Unionida, however much the cardinal teeth may vary in form and direction, they all appear to be formed on one plan; and their formula is thus:-Cardinals Left $\frac{2}{1}$ : with or without Laterals, the left-valved two clasping the right-valved one (vide Pl. IV. fig. 4). Hence in the latter shells the teeth interlock each other completely, and much more securely than in Anthracosia. In the latter genus, however, this defect was undoubtedly compensated by the unusual size of the umbonal portion of the ligament. None of the testiferous specimens which I have examined, of the type of Anthracosia, exhibit the least appearance of posterior teeth; nor do casts of some other species before me afford any indication of their presence in the genus. It will thus be obvious that the genus Cardinia, which possesses well-developed posterior teeth, and which is furnished with some other differential characters, is not the proper group, as some appear to think, for the shells under consideration.

The fulcra of the umbonal ligament of Anthracosia, although simply an enlargement of a peculiar feature of the Unionida, nevertheless form a well-marked character in the diagnosis of the genus. In the typical species they are widish furrows, broadest and deepest on the inner or free margin of the hinge-plate: that of the left valve is more deeply excavated than the right-valved one. The linear impressions of the laminæ forming the umbonal ligament are rather prominently marked on both fulcra, and they curve suddenly down (forming a deep sinus) to the inner margin of the hinge-plate (vide Pl. IV. fig. 2).

Judging from the species represented under fig. 6, Pl. IV., the cartilage appears to have been of the usual size. Several speci-

* Vide Supplementary Note. 
mens have occurred to me in which this structure is equally well preserved; and I perceive that Captain Brown represents it in his Pachyodon (Anthracosia) rugosus*,

The impressions of both adductor muscles are usually well displayed on casts. The anterior one, which is by far the most distinct, is strongly jagged in most species. The pallial line, exhibiting the simple character prevailing generally in the family, is also often very well marked. The scars produced by the anterior pedal muscles are limited to the umbonal cavity and the edge of the hinge-plate, as in Dimyarians generally (vide Pl. IV. fig. 5). I have searched repeatedly and carefully on casts of various species for the supplementary scars, without however observing any that I could safely conclude were such. Occasionally I have seen marks on or near the part where they usually occur; but I feel perfectly satisfied that they can only be considered as accidental, having never seen them on good sharp casts. It is necessary to mention this, as some persons might look upon such marks as having been produced by the supplementary retractors of the foot.

Probably the absence in Anthracosia of a character hitherto never found to be absent in the Unionida, might give rise to the opinion that the genus ought to be placed in another family. Further discoveries may render such a step necessary. I feel persuaded, however, that whatever may hereafter be discovered, the relationship between Anthracosia and the Unionida, contended for in this paper, will not be in the least weakened. At present I am only disposed to go the length of regarding it as the type of an abnornal section of the family.

Anthracosia appears to be confined to deposits of the Carboniferous system; for all the Unionida hitherto described as occurring in secondary and tertiary deposits are normal forms of the family. The Eocene Unio Solandri, and a small Neocomian species before me, exhibit the supplementary scars. Mantell detected them in his Unio Valdensis; and they are well displayed on a Jurassic species found in the Gristhorp plant-beds, and described some years ago by my friend Mr. Bean, under the name of Unio distortus. This specimen appeared to me so interesting as regards the character under consideration, that Mr. Bean kindly allowed me to make the sketeh which is given in Pl. IV. fig. 7.

Although none of the Carboniferous species that I have seen display the supplementary scars, it must not be considered that I have no belief in the existence of normal Unionida during the primary period. The highly interesting form named Anodon

* "Description of some new species of the genus Pachyodon."-Ann. \& Mag. of Nat. Hist. vol. xii. p. 391, Pl. 15. figs. $6 \& 7$ (1843). 
Jukesii by Forbes, and occurring in the Knocktopher plant-beds, is calculated to settle this point; for should it possess the scars in question, the conclusion must arise that normal species of the family existed in the Devonian epoch,-also contemporaneously with Anthracosia.

\section{Supplementary Note.}

Not being able to identify the type of Anthracosia with any published species, I am under the necessity of publishing it as new, naming it after my friend Mr. Bean.

\section{Anthracosia Beaniana, King.}

Diagnosis.-Oval : very inequilateral. Umbones small. Valves thin, rather tumid, and marked with nearly obsolete wrinkles.

This species has some resemblance to Brown's Pachyodon bipennis; but it differs from the latter notably in the anterior end being much shorter. The valves throughout their length are evenly rounded, giving no marked prominence to the umbones. It does not appear to have much exceeded an inch or so in length.

It occurred to me in the coal-measures near Newcastle-onTyne*.

Belmont, near Galway,

December 12, 1855.

\section{EXPLANATION OF PLATE IV.}

Fig. 1. Anthracosia Beaniana, King. a, Left valve (which is restored behind the black line); $b$, Right valve.

Fig. 2. Dental system of the same species ; enlarged. $a+$, posterior slope, $b+$, anterior ridge of cardinal tooth of left valve, $a$; $a$, posterior ridge (fitting on posterior slope $(a+)$ of tooth of opposite valve), $b$, anterior excavation (receiving anterior ridge $(b+)$ of tooth of opposite valve) of right valve, $b$; 0 , o, ligamental fulcra on hingeplate.

Fig. 3. Diagram exhibiting vertical section of cardinal teeth of the same

* A few days ago (Dec. 22) I received from Professor Sedgwick for the Library of Queen's College, Galway, the Third Fasciculus of his "Synopsis of the Classification of the British Palæozoic Rocks," in which I perceive that Professor $\mathbf{M}^{\top} \mathrm{Coy}$ has published a genus under the name Carbonicola. My friend evidently thinks it synonymous with Anthracosia, which he admits being aware that I intended describing! However, if the genus Carbonicola possess the characters diagnosed by Professor M'Coy, it is clearly not the same as my Anthracosia, which does not possess any lateral teeth. There are certain errors in the remarks under the genus Carbonicola which it must be obvious to any one that I am not called on to correct; but it is otherwise with several interspersed throughout the work. Some of those now alluded to, I purpose correcting in future Numbers of the 'Annals,' and the remainder I hope to put right, should I have an opportunity of bringing out a new edition of my Monograph.-Dec. 27, 1855. 
Ann. \& Mag. Nat. Hist. S. 2. Vol. 17. Pl. IV.
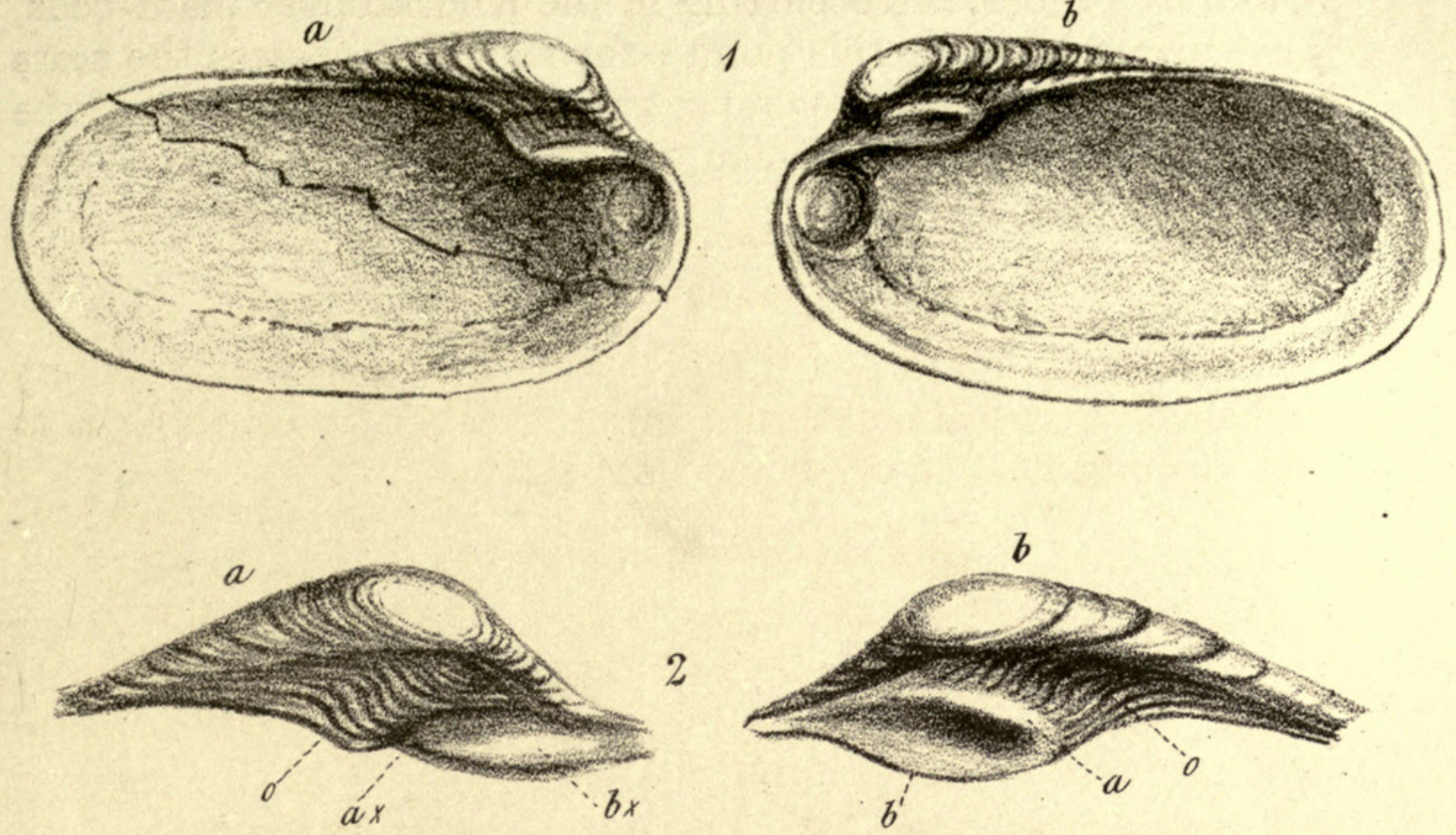

7
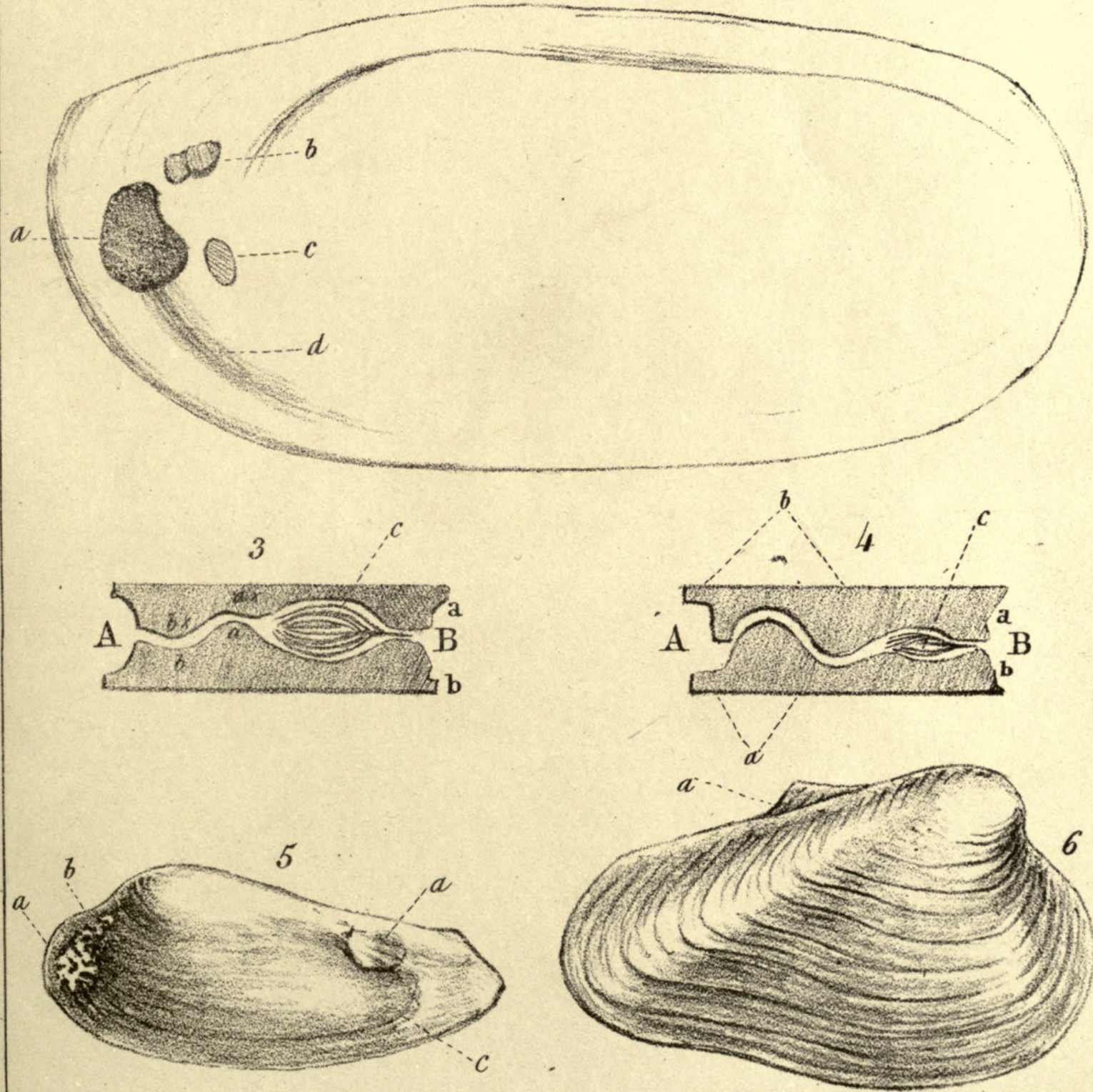


\section{$2 \mathrm{BHL}$ Biodiversity Heritage Library}

King, William. 1856. "VI.-On Anthracosia, a Fossil Genus of the Family Unionidæ." The Annals and magazine of natural history; zoology, botany, and geology 17, 51-57. https://doi.org/10.1080/00222935608697466.

View This Item Online: https://www.biodiversitylibrary.org/item/19391

DOI: https://doi.org/10.1080/00222935608697466

Permalink: https://www.biodiversitylibrary.org/partpdf/11289

\section{Holding Institution}

Natural History Museum Library, London

\section{Sponsored by}

Natural History Museum Library, London

\section{Copyright \& Reuse}

Copyright Status: Public domain. The BHL considers that this work is no longer under copyright protection.

This document was created from content at the Biodiversity Heritage Library, the world's largest open access digital library for biodiversity literature and archives. Visit BHL at https://www.biodiversitylibrary.org. 